\title{
Significance of serum complement levels in patients with gastrointestinal disease
}

\author{
I. N. $\operatorname{ROSS}^{1}, R \cdot A \cdot$ THOMPSON, R. D. MONTGOMERY, AND P. ASQUITH
}

From the Alastair Frazer and John Squire Metabolic and Clinical Research Unit, and the Regional Immunology Laboratory, East Birmingham Hospital, Bordesley Green East, Birmingham, B9 5ST, UK

SUMMARY Levels of the serum complement components, $C_{3}$ and $C_{4}$, in patients with Crohn's disease, ulcerative colitis, and miscellaneous gastrointestinal disorders were compared with those of normal blood donors. Significant increases of both components were found in all three patient groups, the highest being in patients with Crohn's disease. Generally, levels of $\mathrm{C}_{3}$ and $\mathrm{C}_{4}$ were lower in patients with inactive rather than active Crohn's disease and ulcerative colitis.

These results provide some evidence in support of an immunological basis for inflammatory bowel disease. However, in view of the frequent elevation of $C_{3}$ and $C_{4}$ in other gastrointestinal diseases, it is equally possible that the complement components are behaving as acute phase proteins.

In patients with Crohn's disease (CD) and ulcerative colitis (UC) there is evidence of complement activation by both classical and alternative pathways. Thus in active UC elevation of total serum haemolytic complement activity has been reported (Thayer and Spiro, 1963; Fogel et al., 1967) and the $C_{3}$ component has been demonstrated in the rectal mucosa (Ballard and Shiner, 1974). Further, the finding by Doe et al. (1973) of an increased incidence of precipitin reactions with C1q (a fragment of $\mathbf{C}_{1}$ from the classical pathway) in both diseases could indicate the presence of complement-binding immune complexes. Raised serum levels of $\mathrm{C}_{3}, \mathrm{C}_{4}$, and a component of the alternative pathway, factor $\mathrm{B}$, have recently been described (Ward and Eastwood, 1975; Feinstein et al., 1976; Hodgson et al., 1977). Taken together, these findings have been accepted as evidence in favour of an immunological basis for the two diseases, but there has been conflicting evidence, particularly with regard to complement changes in UC (Teisberg and Gjone, 1975; Ward and Eastwood, 1975). We have therefore prospectively compared serum levels of $\mathrm{C}_{3}$ and $\mathrm{C}_{4}$ in patients with $\mathrm{CD}$ and $\mathrm{UC}$ and in a miscellaneous group of other gastrointestinal patients.

\footnotetext{
${ }^{1}$ Present address: Wellcome Research Unit, Christian Medical College Hospital, Vellore, Tamil Nadu, India.
}

Received for publication 31 January 1979

\section{Material and methods}

Serum $C_{3}$ and $C_{4}$ levels were measured in three serial groups: 39 patients with $C D, 35$ with $U C$, and 70 other patients investigated in a gastrointestinal unit (gastrointestinal controls, Table 1) and also in a group of 100 normal blood donors. The diagnosis of $\mathrm{CD}$ and UC was based on accepted clinical, radiological, and pathological criteria; disease activity was determined using the criteria of Truelove and Witts (1955) for UC and of De Dombal et al. (1974) for CD, taken in conjunction with the results of serum levels of albumin and orosomucoid.

Serum albumin was determined by a standard autoanalytical technique (Northam and Widdowson, 1967) and serum orosomucoid by a M-Partigen Immunodiffusion plate (Behringwerke AG, West Germany); serum $\mathrm{C}_{3}$ and $\mathrm{C}_{4}$ levels were measured by the modified single diffusion technique of Mancini et al. (1965) using monospecific antisera.

Statistical analysis was performed by calculating fiducial limits based on Student's $t$ distribution, as described by Bliss (1967) for samples with unequal variances.

\section{Results}

The mean $( \pm 1 \mathrm{SD})$ levels of serum $\mathrm{C}_{3}$ and $\mathrm{C}_{4}$ in the four groups of subjects, together with the $\mathrm{P}$ value for the difference between these means, are shown in Table 2, and the results for individual patients are presented in Figures 1 and 2. 
Table 1 Patient diagnosis in gastrointestinal controls; the numbers in each diagnostic category with an elevated serum $C_{3}$ and/or $C_{4}$ level are also shown

\begin{tabular}{|c|c|c|c|}
\hline \multirow[t]{2}{*}{ Diagnosis } & \multirow[t]{2}{*}{ Number of patients } & \multicolumn{2}{|c|}{ Individuals with elevated levels* } \\
\hline & & $C_{3}$ & $C_{4}$ \\
\hline Coeliac disease & 15 & 1 & 2 \\
\hline Irritable bowel syndrome & 14 & 4 & 7 \\
\hline Iron and/or folate deficiency & 9 & 4 & 4 \\
\hline Peptic ulceration/post-gastrectomy diarrhoea & 4 & 2 & 1 \\
\hline Pernicious anaemia & 3 & 2 & 2 \\
\hline Chronic pancreatitis & 3 & & 1 \\
\hline Whipple's disease & 2 & & 1 \\
\hline Hypogammaglobulinaemia and malabsorption & 2 & & 1 \\
\hline Alcoholic cirrhosis & 2 & & \\
\hline Ileocaecal tuberculosis & 2 & & 1 \\
\hline Thyrotoxic diarrhoea & 2 & & \\
\hline Malabsorption due to intestinal resection & 2 & & 1 \\
\hline a-Heavy chain disease & $\overline{1}$ & & 1 \\
\hline Pneumatosis cystoides & 1 & 1 & \\
\hline Osler-Weber-Rendu syndrome & 1 & & \\
\hline Nutritional vitamin D deficiency & 1 & 1 & \\
\hline Lactose intolerance & 1 & & \\
\hline Tropical sprue & 1 & & \\
\hline Small intestinal diverticula & 1 & & \\
\hline Diverticulitis & 1 & & 1 \\
\hline Eosinophilic gastroenteritis & 1 & 1 & 1 \\
\hline Primary intestinal lymphangiectasia & 1 & 1 & 1 \\
\hline
\end{tabular}

*Flevated level $=$ value $>$ normal control mean +2 SD

Comparison between $\mathrm{C}_{3}$ and $\mathrm{C}_{4}$ levels in each of the three patient groups showed significant differences, the $C D$ group having the highest mean values. In addition, the mean $\mathrm{C}_{3}$ and $\mathrm{C}_{4}$ values in these three patient groups, which included the gastrointestinal control group, were significantly higher than in the normal controls. Of $10 \mathrm{CD}$ patients with a $\mathrm{C}_{3}$ level within the normal control range (mean $\pm 2 \mathrm{SD}$ ), only four had active disease. The complement levels in two of these four patients were measured at a time when they were extremely ill with $C D$, and both have subsequently died of their disease. Complement levels in patients with inactive disease tended to be lower than in those with active disease; 10 out of $11\left(\mathrm{C}_{3}\right)$ and nine out of 11 $\left(\mathrm{C}_{4}\right)$ patients with inactive $\mathrm{CD}$ had levels below the mean of the $C D$ group, while seven out of $13\left(C_{3}\right)$ and nine out of $13\left(\mathrm{C}_{4}\right)$ with inactive UC had levels below the mean of their group. Concurrent elevation of both $\mathrm{C}_{3}$ and $\mathrm{C}_{4}$ in individual patients occurred in about $50 \%$ of cases. The diagnoses of the gastrointestinal control patients with elevated $\mathrm{C}_{3}$ and/or $\mathrm{C}_{4}$ levels are listed in Table 1.

There was no correlation between serum orosomucoid levels and levels of $\mathrm{C}_{3}$ or $\mathrm{C}_{4}$ in either $\mathrm{CD}$ or $\mathrm{UC}$, in serial samples taken from individual patients.

\section{Discussion}

Our results clearly indicate an altered complement metabolism with respect to $C_{3}$ and $C_{4}$ complement components in CD and UC. Only $16 \%$ of patients with active disease had complement values within the normal control range, and, in addition, levels of

Table 2 Mean levels of serum $C_{3}$ and $C_{4}( \pm 1 S D)$ in the three patient groups and in the normal controls, together with the significance of the difference between means. Complement expressed as $\mathrm{mg} / 100 \mathrm{ml}$

\begin{tabular}{|c|c|c|c|c|c|}
\hline \multirow[t]{2}{*}{ Complement component } & \multirow[t]{2}{*}{ Patient group } & \multirow[t]{2}{*}{ Mean $\pm 1 S D$} & \multicolumn{3}{|c|}{ Significance of difference between means } \\
\hline & & & $C D$ & $U C$ & Gastrointestinal control \\
\hline \multirow{4}{*}{$\begin{array}{l}C_{3} \\
" \\
"\end{array}$} & CD & $199 \pm 56$ & - & - & - \\
\hline & UC & $174 \pm 43$ & $P<0.05$ & - & - \\
\hline & $\begin{array}{l}\text { Gastrointestinal } \\
\text { control }\end{array}$ & $146 \pm 40$ & $P<0.001$ & $\mathbf{P}<0.01$ & - \\
\hline & Normal control & $120 \pm 21$ & $P<0.001$ & $P<0.001$ & $P<0.001$ \\
\hline \multirow{4}{*}{$\begin{array}{l}\text { C. } \\
", \\
"\end{array}$} & CD & $56 \pm 20$ & - & - & - \\
\hline & UC & $48 \pm 13$ & $P<0.05$ & - & - \\
\hline & $\begin{array}{l}\text { Gastrointestinal } \\
\text { control }\end{array}$ & $42 \pm 17$ & $P<0.001$ & $P<0.05$ & - \\
\hline & Normal control & $30 \pm 7 \cdot 5$ & $P<0.001$ & $P<0.001$ & $P<0.001$ \\
\hline
\end{tabular}




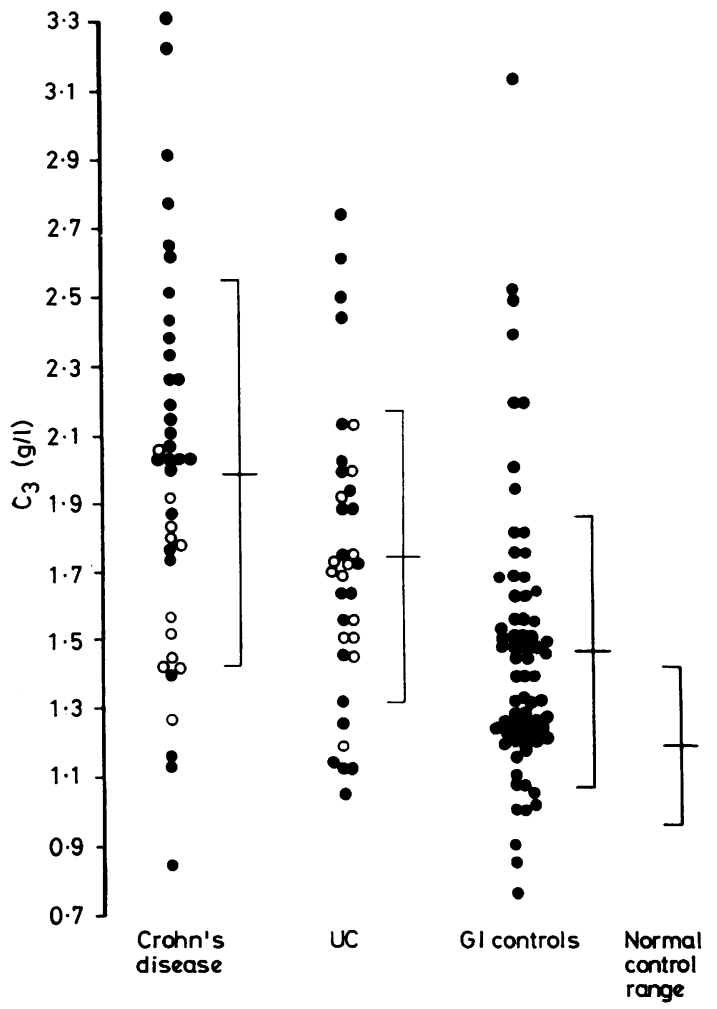

Fig. $1 C_{3}$ levels in individual patients. Brackets indicate mean $\pm S D$ for that group. White circles indicate inactive disease.

both components were lower in quiescent $\mathrm{CD}$ and UC.

These findings are in keeping with the results reported by Thayer and Spiro (1963) for total haemolytic complement in UC, elevated values being found in active disease. Subsequently, Feinstein et al. (1976) and Hodgson et al. (1977) found the serum factor B level to be raised in both conditions, particularly in $C D$, and remission of the inflammatory bowel disease was associated with a fall in this level. Hodgson et al. (1977) also reported significantly elevated levels of serum $C_{3}$ in $C D$ and an elevation of serum C1q in both CD and UC. In contrast, Teisberg and Gjone (1975) and Ward and Eastwood (1975) were unable to demonstrate significant elevation of $\mathrm{C}_{3}$ or $\mathrm{C}_{4}$ in inflammatory bowel disease (except for $\mathrm{C}_{4}$ in $\mathrm{CD}$ in the latter study).

In spite of these varying results there is additional evidence of altered complement activity in inflammatory bowel disease, namely (i) $\mathrm{C}_{3}$ conversion as shown by the presence of $\mathrm{C}_{3}$ breakdown products in blood (Teisberg and Gjone, 1975), (ii) the presence

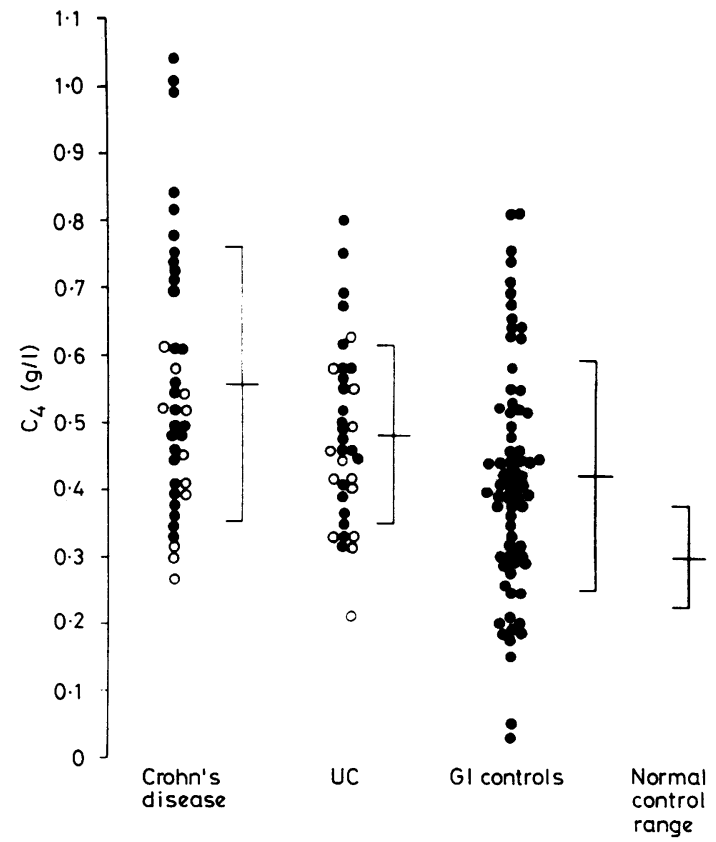

Fig. $2 C_{4}$ levels in individual patients. Brackets indicate mean $\pm S D$ for that group. White circles indicate inactive disease.

of low titres of immunoconglutinins reflecting continuing complement activation (Pepys et al., 1977), and (iii) an increased fractional catabolic rate as well as synthetic rate of the $\mathrm{C}_{3}$ component (Hodgson et al., 1977).

With respect to mechanisms, it has been postulated that the site of complement activation is within the gut mucosa itself, initiated by antigenantibody reactions. However, it is equally possible that the high titres of $\mathrm{C}_{3}$ and $\mathrm{C}_{4}$ demonstrated in this study represent acute phase reactants. $\mathrm{C}_{3}, \mathrm{C}_{4}$, $\mathrm{C}_{5}, \mathrm{C}_{6}$, and factor B are known to be 'acute phase' proteins of acute inflammation (Schutte et al., 1974; Lachmann, 1975). Both $C_{3}$ and factor $B$ originate in the liver, as do other acute phase proteins; these include orosomucoid, which is elevated in active CD (Cooke et al., 1958). Nevertheless, in our patients with active $C D$ comparison of serial $C_{3}$ or $C_{4}$ levels with orosomucoid levels showed no correlation.

Additional evidence that $\mathrm{C}_{3}$ and $\mathrm{C}_{4}$ behave as acute phase reactants is suggested by the elevated values found in patients with gastrointestinal disease other than inflammatory bowel disease, and in hospital patients without immunological disorders in the report from Hodgson et al. (1977). It is difficult to explain the cause of raised complement levels in seven out of 14 patients who, after intensive 
investigation, including jejunal biopsy and barium studies, were classified as having an irritable bowel syndrome, and this finding is perhaps worthy of further study.

We thank Dr H. G. Sammons, in whose laboratories the serum albumin and orosomucoid estimations were performed, and Professor J. Hardwicke for viewing the manuscript and for his helpful criticisms.

\section{References}

Ballard, J., and Shiner, M. (1974). Evidence of cytotoxicity in ulcerative colitis from immunofluorescent staining of the rectal mucosa. Lancet, 1, 1014-1017.

Bliss, C. I. (1967). Statistics in Biology, Volume 1, p. 215. McGraw-Hill, New York.

Cooke, W. T., Fowler, D. I., Cox, E. V., Gaddie, R., and Meynell, M. J. (1958). The clinical significance of seromucoids in regional ileitis and ulcerative colitis. Gastroenterology, 34, 910-919.

De Dombal, F. T., Burton, I. L., Clamp, S. E., and Goligher, J. C. (1974). Short-term course and prognosis of Crohn's disease. Gut, 15, 435-443.

Doe, W. F., Booth, C. C., and Brown, D. L. (1973). Evidence for complement-binding immune complexes in adult coeliac disease, Crohn's disease, and ulcerative colitis. Lancet, 1, 402-403.

Feinstein, P. A., Kaplan, S. R., and Thayer, W. R., Jr. (1976). The alternate complement pathway in inflammatory bowel disease. Quantitation of the $C_{3}$ proactivator (Factor B) protein. Gastroenterology, 70, 181-185.

Fogel, B. J., Hook, W. A., and Polish, E. (1967). A note on serum complement activity with particular reference to ulcerative colitis. Military Medicine, 132, 282-285.

Hodgson, H. J. F., Potter, B. J., and Jewell, D. P. (1977).
Humoral immune system in inflammatory bowel disease. I. Complement levels. Gut, 18, 749-753.

Lachmann, P. (1975). Complement. In Clinical Aspects of Immunology, 3rd edition, edited by P. G. H. Gell, R. R. A. Coombs, and P. J. Lachmann, pp. 323-364. Blackwell, Oxford.

Mancini, G., Carbonara, A. O., and Heremans, J. F. (1965). Immunochemical quantitation of antigens by single radial immunodiffusion. Immunochemistry, 2, 235-254.

Northam, B. E., and Widdowson, G. M. (1967). The determination of serum albumin by AutoAnalyser using Bromocresol green. Technical Bulletin, No. 11, Association of Clinical Biochemists, London.

Pepys, M. B., Druguet, M., Klass, H. J., Dash, A. C., Mirjah, D. D., and Petrie, A. (1977). Immunological studies in inflammatory bowel disease. In Immunology of the Gut, edited by J. Knight. (Ciba Foundation symposia, No. 46) pp. 283-304. Elsevier, Amsterdam.

Schutte, M., DiCamelli, R., Murphy, P., Sadove, M., and Gewurz, H. (1974). $C_{3}$ proactivator $\left(C_{3} P A\right)$ as an acute phase reactant. Clinical and Experimental Immunology, 18, 251-256.

Teisberg, P., and Gjone, E. (1975). Humoral immune system activity in inflammatory bowel disease. Scandinavian Journal of Gastroenterology, 10, 545-549.

Thayer, W. R., Jr., and Spiro, H. M. (1963). Persistence of serum complement in sera of patients with ulcerative colitis. Journal of Laboratory and Clinical Medicine, 62, 24-30.

Truelove, S. C., and Witts, L. J. (1955). Cortisone in ulcerative colitis: final report on a therapeutic trial. British Medical Journal, 2, 1041-1048.

Ward, M., and Eastwood, M. A. (1975). Serum $C_{3}$ and $C_{4}$ complement components in ulcerative colitis and Crohn's disease. Digestion, 13, 100-103.

Requests for reprints to: Dr P. Asquith, The Alastair Frazer and John Squire Metabolic and Clinical Research Unit, East Birmingham Hospital, Birmingham B9 5ST. 